\title{
TEACHING STUDENT'S SPEAKING ABILITY USING TIME TOKEN ARENDS
}

\author{
Mira Nurjanah ${ }^{1}$, Ahmad Hambali ${ }^{2}$, Sri Supiah Cahyati \\ ${ }^{1}$ IKIP Siliwangi \\ ${ }^{2}$ IKIP Siliwangi \\ ${ }^{3}$ IKIP Siliwangi \\ ${ }^{1}$ miranurjanah444@yahoo.com, ${ }^{2}$-ahambali25@gmail.com, ${ }^{3}$ srisupiahcahyati02@gmail.com
}

\begin{abstract}
Speaking is one of skills that should be mastered by all of students who learn English. However, passive students face some difficulties in speaking. They are less confident, so they difficult to talk in present of the class. Regarding this, the teacher should teach using appropriate strategy to improve students' speaking ability and to increase their confidence. This research was conducted to find out whether Time Token Arends can improve students' speaking ability. This research was arranged using Classroom Action Research. The sample taken by using purposive sampling technique. The writers took 32 students of class X IPS 1 in one of a senior high school in Cianjur as the sample of this research. The result showed that Time Token Arends can improve students'speaking ability, especially in encouraging passive students become active students.
\end{abstract}

Keywords: Teaching speaking, Time Token Arends.

\section{INTRODUCTION}

Speaking is one language skills the students of secondary schools are suppose to have beside listening, reading, and writing. In teaching speaking, the English teacher should be carry on to design many communicative actions in the classroom to support and induce students to employ the language entusiastically and effectively. For this, the teachers should be aware of their students who can speak in limited time, also the students who do not know to speak and how to communicate their ideas or opinions to others.

In addition, the characteristics of students are different. From participation, the students can be divided as active and passive students. In teaching learning process in the class, active students can be known by velocity to respond teacher's instruction. Otherwise, the passive students can be known by less to respond teacher's instruction. One of disadvantages of passive students is less of confidence to say their ideas so they will be left behind from active students. Furthermore, the teachers should make appropriate tactics that can be used for active students and passive students to improve students' speaking ability.

One of strategies that can be applied to improve the students' speaking ability is Time Token Arends. According to (Arends, 2009), Time Token Arends is a approach that can be used in situation where there are some people dominate the conversation and some other are shy and never say anything. Time Token Arends can be used to improve the students' speaking ability and also can improve the students' participation in developing skill and bravery to have an idea in the learning language. Teaching speaking using Time Token Arends useful to motivate and activate the students to speak English. 
Based on explanation above, the writers conducted a research entitled "Teaching Student's Speaking Ability using Time Token Arends.

\section{METHOD}

In this research, the writers engaged qualitative research design and the population of this research was the tenth grade students in one of Senior High School in Cianjur.In this research the sample was selected by using purposive sampling technique. Purposive sampling is selecting a sample "on the source of your own information of the population, its elements, and the environment of your research aims"(Babie, 1990). The researcher chose X IPS 1 because the students of X IPS 1 were less of confidence in speaking ability. So, the writers took this class as the sample. Research method is an important thing of research because it shows the style of conducting research. In this research the researchers used Classroom Action Research (CAR) as the research method. The classroom action research is an analysis of education activities in the form of an action research which deliberately and it occurs in a classroom together (Arikunto, 2013). The Classroom Action Research was contained in two cycles. The figure of CAR was designd by Kemmis and Mc Taggart in (Arikunto, 2013) as following:

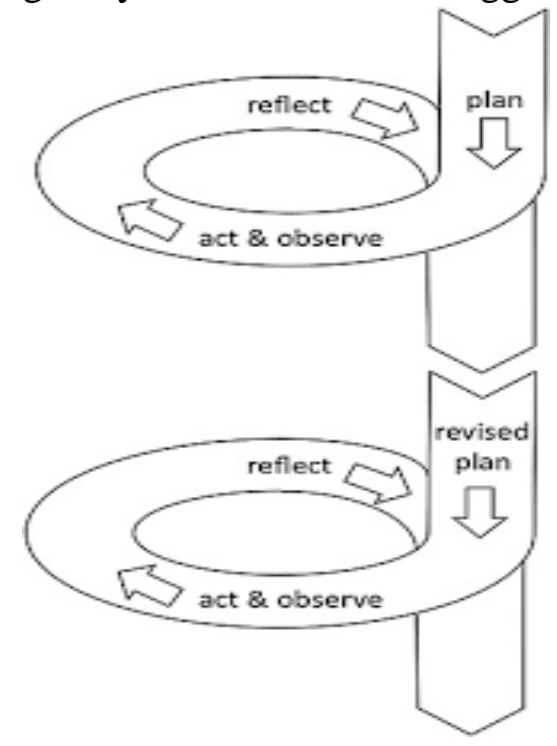

Figure 1. Figure of Classroom Action Research

Furthermore, there are four steps of each cycles. The first is planning, this step is making lesson plan from syllabus. The second step is acting, here the activites are based on lesson plan,they are: Starting activites:Greeting and Giving motivation; Core activites:The teacher explained the purpose teaching learning process and basic competence, The teacher organized the class for discussion, she gave 3 cards (token) for all of students in 30 second per one card.After studens spoke, the card that they hold was given to the teacher, The student who used up all of cards was not allowed to speak meanwhile the students that still had the cards should speak till used up all the cards;Last activites: the teacher and the students made conclusion from the result of material and Greeting. The third step is observing, here the researcher observed the students during teaching-learning process using Time TokenArends. And the last step is reflecting, the researcher reflected to see the result of teaching learning process using Time TokenArends. Then the result of reflecting in one cycle became a hint to improve teaching learning-process in next cycle.

In giving scores, the writers referred to the scoring categories which is proposed by (Brown, 2001). 
Table 1. Scoring Categories

\begin{tabular}{|c|c|c|c|}
\hline No & Aspect & Score & Description \\
\hline \multirow{5}{*}{1} & \multirow{5}{*}{ Grammar } & 1 & $\begin{array}{l}\text { Errors in grammar are frequent, but speaker can be } \\
\text { unstated by a native speaker used to selling with foreigner }\end{array}$ \\
\hline & & 2 & $\begin{array}{l}\text { Can usually stem elementary constructions rather correctly } \\
\text { but have not through or secure control of the grammar. }\end{array}$ \\
\hline & & 3 & $\begin{array}{l}\text { Control of grammar is good. It can be concluded that to } \\
\text { speak the language with stuctural enough coincidentally to } \\
\text { respondent clearly in most formal and informal dialogues } \\
\text { on sensible, common and expert topics. }\end{array}$ \\
\hline & & 4 & $\begin{array}{l}\text { Able to apply the language efectively on all levels in } \\
\text { general relevant to expert needs. Errors in grammar are } \\
\text { quite rare }\end{array}$ \\
\hline & & 5 & Equivalent the aim of an knowledgeble native speaker. \\
\hline \multirow{5}{*}{2} & \multirow{5}{*}{ Vocabulary } & 1 & $\begin{array}{l}\text { Speaking vocabulary inadequate to express anything but } \\
\text { the most elementary needs }\end{array}$ \\
\hline & & 2 & $\begin{array}{l}\text { Has speaking vocabulary enough to communicate himself } \\
\text { cleanly with any past words. }\end{array}$ \\
\hline & & 3 & $\begin{array}{l}\text { Able to talk the language with adequate vocabulary to } \\
\text { respondent succsessfully in most formal and informal } \\
\text { dialogues on practical, social and professional topics. } \\
\text { Vocabulary is extensive enough that he seldom has to } \\
\text { fumble for a word. }\end{array}$ \\
\hline & & 4 & $\begin{array}{l}\text { Can recognize and contribute in any dialogues within the } \\
\text { range of his practice with a high level of precision of } \\
\text { vocabulary. }\end{array}$ \\
\hline & & 5 & $\begin{array}{l}\text { Speech on all categories is completely received by learned } \\
\text { native speakers in all its skin containing breadth of } \\
\text { vocabulary and sinonims, behaviour words and pertinent } \\
\text { cultural references. }\end{array}$ \\
\hline \multirow{5}{*}{2} & \multirow{5}{*}{ Comprehension } & 1 & $\begin{array}{l}\text { Within the possibility of his very poor language } \\
\text { knowledge, can comprehend easy questions and } \\
\text { statements if with slowed speech, repetition or paraphrase }\end{array}$ \\
\hline & & 2 & $\begin{array}{l}\text { Can obtain the idea of most dialogues of non-technical } \\
\text { subjects. (i.e., topics to involve no spesific knowledge) }\end{array}$ \\
\hline & & 3 & $\begin{array}{l}\text { Comprehension is rather complete at a common rate of } \\
\text { talk. }\end{array}$ \\
\hline & & 4 & $\begin{array}{l}\text { Can understand some dialogues inside the distance of his } \\
\text { experience. }\end{array}$ \\
\hline & & 5 & Equivalent is a learned of native speaker. \\
\hline \multirow[b]{2}{*}{3} & \multirow[b]{2}{*}{ Fluency } & 1 & (there is no detail description. less of four language skill) \\
\hline & & 2 & $\begin{array}{l}\text { Good in confident, but there is no facilate situations, } \\
\text { containing in opening and common dialogues about a new } \\
\text { events, although work, family and autobiographical } \\
\text { information. }\end{array}$ \\
\hline \multirow{2}{*}{4} & & 3 & $\begin{array}{l}\text { Good in talk about exact interests of skill with practical } \\
\text { ease and seldom to grope for words. }\end{array}$ \\
\hline & & 4 & $\begin{array}{l}\text { Enough in using the language on all categories and to } \\
\text { professional needs. }\end{array}$ \\
\hline
\end{tabular}




\begin{tabular}{|c|c|c|c|}
\hline & & 5 & $\begin{array}{l}\text { Very good in completing fluency in the language, } \\
\text { especially in receiving of native speakers' education. }\end{array}$ \\
\hline \multirow{5}{*}{5} & \multirow{5}{*}{ Pronunciation } & 1 & $\begin{array}{l}\text { Errors in pronunciation are frequent but can be understood } \\
\text { by a native speaker used to dealing with foreigners } \\
\text { attempting to speak his language. }\end{array}$ \\
\hline & & 2 & Accent is intelligible though often quite faulty. \\
\hline & & 3 & $\begin{array}{l}\text { Errors never interfere with understanding and rarely } \\
\text { disturb the native speaker. Accent may be obviously } \\
\text { foreign }\end{array}$ \\
\hline & & 4 & Errors in pronunciation are quite rare. \\
\hline & & 5 & $\begin{array}{l}\text { Equivalent to and fully accepted by educated native } \\
\text { speakers. }\end{array}$ \\
\hline \multirow{5}{*}{6} & \multirow{5}{*}{ Task } & 1 & $\begin{array}{l}\text { Enough in aswering ask and answer questions of native } \\
\text { speaker. But minimum in attitude requirements. }\end{array}$ \\
\hline & & 2 & $\begin{array}{l}\text { Enough in activities fulfill and routine social claim and } \\
\text { work requirements; necessity help in controlling some } \\
\text { troubles or difficulties. }\end{array}$ \\
\hline & & 3 & $\begin{array}{l}\text { Good in respondent succsessfully in most formal and } \\
\text { informal dialogues on practical, social and professional } \\
\text { materials. }\end{array}$ \\
\hline & & 4 & $\begin{array}{l}\text { Seldom in taking a native speaker but can participate } \\
\text { properly even in unfamiliar situations. Can control } \\
\text { informal interpreting form and into language. }\end{array}$ \\
\hline & & 5 & $\begin{array}{l}\text { Speaking competence is good. Especially in equally of an } \\
\text { learned of native speaker. }\end{array}$ \\
\hline
\end{tabular}

Moreover to know the real score of students, the writers used the following formula :

$$
\mathrm{RS}=\frac{\mathrm{TS}}{30} \times 100
$$

Where :

$\mathrm{RS}=$ Real Score of each individual

TS $=$ Total Score of the aspect of speaking

$30=$ The possible highest scores that students get from the teacher

(Hatch \& Farhady, 1982) in (Aratry. S, Rumiri, A. \& Desri, 2017)

\section{RESULTS AND DISCUSSION}

\section{Results}

In this research consisted of two cycles, here are the reports of students speaking test in two cycles.

The result of speaking test in cycle 1 shows that the student's mean score was still low. It was 65.25 which was catagorized in average level. 
Table 3. Students' Speaking score in cycle 1.

\begin{tabular}{cccc}
\hline No. & $\begin{array}{c}\text { Test score } \\
\text { interval }\end{array}$ & Level & The total of students in the percentage (\%) \\
1 & $81-100$ & Excellent & $0(0 \%)$ \\
2. & $61-80$ & Good & $8(25 \%)$ \\
3. & $41-60$ & Average & $24(75 \%)$ \\
4. & $21-40$ & Fair & $0(0 \%)$ \\
5. & $0-20$ & Poor & $0(0 \%)$ \\
\hline \multicolumn{2}{l}{ Total of students } & & 32 \\
Mean score & & 65.25 \\
Category & & Good \\
\hline
\end{tabular}

In addition, cycle 2 shows that the mean score of student's speaking test was 70.25 and it was catagorized as good level.

Table 4. Students' Speaking score in cycle 2.

\begin{tabular}{cccc}
\hline $\begin{array}{l}\text { No. } \\
\text { interval }\end{array}$ & $\begin{array}{l}\text { Test } \\
\text { score }\end{array}$ & Level & The total of students in the percentage $(\%)$ \\
\hline 1 & $81-100$ & Excellent & $0(0 \%)$ \\
2. & $61-80$ & Good & $12(37.5 \%)$ \\
3. & $41-60$ & Average & $20(62.5 \%)$ \\
4. & $21-40$ & Fair & $0(0 \%)$ \\
5. & $0-20$ & Poor & $0(0 \%)$ \\
\hline \multicolumn{2}{l}{ Total of students } & & 32 \\
Mean score & & 70.25 \\
\hline
\end{tabular}

\section{Discussion}

From the tables in the result of the research above, there was improvement of score from cycle 1 to cycle 2 . The following chart show the detail improvement:

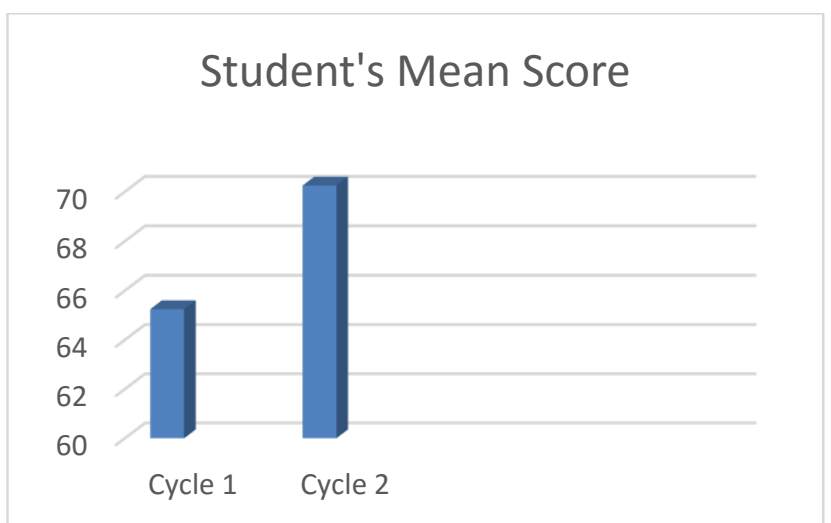

Chart 1. The comparison of student's score in Cycle 1 and Cycle 2

The chart showed that there was a kind of significant improvement of student's speaking mean score from cycle $1(62.25)$ to cycle 2 (70.25). Thus it can be stated that teaching student's speaking using Time Token Arends can improve student's speaking ability of the tenth grade in one of Senior High School in Cianjur. 


\section{CONCLUSION}

Based on the finding and the discussion, it showed that the students' speaking ability using Time Token Arends improved from cycle 1 and cycle 2. The improvement can be seen from the students' speaking score test. In cycle 1 the mean score was 62.25 , while in cycle 2 the mean score was 70.25. Generally, significant difference was improved that was 10.00 . In conclusion, it can be stated that using Time Token Arends can improve students' speaking ability.

\section{ACKNOWLEDGMENTS}

Alhamdulillahirrobil'alamiin this paper has been finished, first of all we would say thank to Allah SWT, because of him this paper would not have been possible to finish. The second we also would say thank to our lecturer that always give us support and she has taugh us until this paper has finished, may Allah SWT always bless her. And the last we would say thank to our parents for their support and financial. May Allah also bless them and gives them happiness. Aamiin YaRobbal'alamiin.

\section{REFERENCES}

Aratry. S, Rumiri, A. \& Desri, M. S. (2017). The Effect of Please Strategy on the Ability of the first year Students of SMPN 5 Pekan baru in Paragraph writing. FKIP Universitas Riau.

Arends, R. (2009). Learning to teach. United States: McGraw Hill.

Arikunto, S. (2013). Prosedur Penelitian. Jakarta: PT. Rineka Cipta.

Babie, E. (1990). Survey Research Methods (2nd ed.). California: Wadsworth Publishing company, 2nd ed.

Brown, H. D. (2001). Principles of Language Learning and Teaching (5 editions). New York: Pearson Education Inc.

Hatch, E. M., \& Farhady, H. (1982). Research design and statistics for applied linguitics. Rowley, Mass: Newbury House. 